\title{
An Innovative Educational and Mentorship Program for Emergency Medicine Women Residents to Enhance Academic Development and Retention
}

\author{
Kriti Bhatia, MD*; James Kimo Takayesu, MD, MSc ${ }^{\dagger}$; Christian Arbelaez, MD, MPH*; David Peak, MD ${ }^{\dagger}$; \\ Eric S. Nadel, $\mathrm{MD}^{*}$
}

\begin{abstract}
Given the discrepancy between men and women's equal rates of medical school matriculation and their rates of academic promotion and leadership role acquisition, the need to provide mentorship and education to women in academic medicine is becoming increasingly recognized. Numerous large-scale programs have been developed to provide support and resources for women's enrichment and retention in academic medicine. Analyses of contributory factors to the aforementioned discrepancy commonly cite insufficient mentoring and role modeling as well as challenges with organizational navigation. Since residency training has been shown to be a critical juncture for making the decision to pursue an academic career, there is a need for innovative and tailored educational and mentorship programs targeting residents. Acknowledging residents' competing demands, we designed a program to provide easily accessible mentorship and contact with role models for our trainees at the departmental and institutional levels. We believe that this is an important step towards encouraging women's pursuit of academic careers. Our model may be useful to other emergency medicine residencies looking to provide such opportunities for their women residents.
\end{abstract}

\section{RÉSUMÉ}

Compte tenu de l'écart qui existe entre les hommes et les femmes en ce qui concerne l'égalité des taux d'inscription dans les écoles de médecine mais l'inégalité des taux de promotion et de nomination à des rôles de direction, la nécessité d'offrir du mentorat et de la formation aux femmes en médecine universitaire s'impose de plus en plus. De nombreux programmes appliqués à grande échelle ont été élaborés afin de fournir du soutien et des ressources aux femmes en vue de leur perfectionnement et de leur maintien en médecine universitaire. Sont souvent invoqués, dans les analyses des facteurs qui jouent un rôle dans cet écart, le manque de mentorat et de modèles de rôle ainsi que les difficultés de s'y retrouver dans les organisations. Des études ayant démontré que la résidence constituait une étape cruciale dans la poursuite d'une carrière universitaire, il est nécessaire d'avoir des programmes novateurs et adaptés de formation et de mentorat, qui ciblent les résidentes. Reconnaissant les demandes concurrentielles des résidentes, les auteurs ont élaboré un programme qui vise à offrir aux stagiaires des possibilités de mentorat et d'établissement de relations avec des modèles de rôle, et ce, tant au niveau du département qu'au niveau de l'établissement. Les auteurs croient qu'il s'agit là d'une étape importante afin d'inciter les femmes à poursuivre une carrière universitaire. Le modèle décrit ici peut se montrer utile dans d'autres programmes de résidence en médecine d'urgence en vue d'offrir aux résidentes ce genre de possibilités.

\section{BACKGROUND}

Women graduate in equal numbers from medical school as men but comprise less than half of academic faculties. ${ }^{1,2}$ Within academic settings, their rate of promotion and appointment to leadership roles lags significantly behind their male counterparts', and their attrition rate exceeds that of men. ${ }^{1-3}$ Cited reasons include lack of perceived positive role models and insufficient support, mentorship and preparation., Women have more difficulty identifying potential mentors, despite seeking them more often than men do. ${ }^{4}$ Women also report satisfying mentoring relationships less frequently. ${ }^{4,5}$ The literature suggests that women may have specific mentoring needs and benefit from female mentors. ${ }^{4}$ Effective mentoring can enhance career satisfaction and professional development and has been linked to career choice, including the decision to pursue an academic career..$^{5-7}$ Recent studies have demonstrated that women enter residency with comparable intention to pursue academic careers as men, but that their interest declines as training progresses. $^{7}$ Residency is a critical time period to choose an academic career. However, studies show that

From the *Department of Emergency Medicine, Brigham and Women's Hospital, Boston, MA; and †Department of Emergency Medicine, Massachusetts General Hospital, Boston, MA.

Correspondence to: Kriti Bhatia, MD, Brigham and Women's Hospital, Department of Emergency Medicine, 75 Francis Street, Neville House, Room 236-C, Boston, MA 02115; Email: kbhatia1@ partners.org 
residents perceive their acquisition of academic skills to be suboptimal. ${ }^{8}$

Numerous organizations with the mission of educating, supporting and mentoring women physicians to enhance recruitment and retention in academic medicine have been created. However, there are few reports describing local or departmental programs specifically for women in emergency medicine (EM), and there are no programs, to our knowledge, exclusively for women residents. An environmental scan of Canadian EM residencies conducted using a combination of direct inquiry of program directors via email and a review of program websites did not identify any such programs. As more women enter EM, such programs may have significant impact.

\section{RATIONALE}

Given the paucity of women's programs exclusively for residents, we performed a needs-assessment in our residency program. We assembled a focus group of eight female residents and administered a questionnaire to all female residents, which had a $75 \%$ response rate. None of the respondents utilized national women's resources due to time limitations, challenges navigating the organization or website, and lack of resource proximity. Emergency physicians face unique challenges given the nature of our work and schedules that general medical organizations may not address. We therefore designed and implemented a program for women residents to provide accessible role modeling and mentorship, as well as education in critical skills required to succeed in academic EM. ${ }^{7}$

\section{DESCRIPTION OF THE INNOVATION}

Our program was developed to provide an evidencebased framework of topics and informal mentorship opportunities. Topics were established after medical and business literature searches identified key components of leadership development and mentorship for women, reasons that women choose non-academic careers, and unique challenges in EM. Our program is multifaceted in order to maximize outreach.

We organized evening mentorship events hosted by faculty volunteers to establish contact and provide an ongoing support structure. A pre-selected theme and corresponding article were used to focus discussion with faculty, who offered experiential expertise.
(Table 1) Discussions incorporated resident-specific needs, including strategies to secure academic jobs, interviewing tips, negotiation tactics for jobs and clinical practice, methods to navigate institutional systems as new faculty, ways to prevent burnout, and time management techniques for academic productivity in the context of shift work. Resident leaders encouraged attendance and participation and were instrumental in theme selection to ensure topical relevance to resident needs. Event evaluations $(n=24)$ were uniformly positive. In all, $81.8 \%$ of senior residents said that the events provided them with mentorship and insight into life as an academician that they have not received elsewhere. For $76.4 \%$ of attendees, the events provided skills and insight to better inform their practice choice and prepare them for academics.

We developed an online repository of resources accessible to all residents. Resources include information about useful institutional resources, information about challenges women in academics encounter, and educational articles about skills integral to academics, including public speaking, interviewing, and teaching techniques. In addition, a list of female faculty advisors includes residency graduates, physicians at local hospitals, and physicians from other departments willing to provide career and personal guidance.

Partnering with our institution's Office for Women's Careers, we co-sponsored a roundtable discussion for women trainees. Women faculty led discussions covering topics that included academic career advancement, finding mentorship, leadership development, and family-career balance. The format was interactive and provided cross-discipline, experiential mentorship and networking opportunities. Evaluations were uniformly positive, rated 4.89 out of $5(\mathrm{n}=15$ respondents). Attendees commented most frequently that the session encouraged them to develop a broader network of mentors.

\section{DISCUSSION}

Recruiting and retaining women in academic medicine can enhance the future of women in medicine by providing role models and relatable mentorship. Residency is a catalytic period in choosing an academic career, yet programs exclusively targeting female trainees and their specific needs are sparse. Statistics showing that women preferentially choose non-academic careers, or leave 
Table 1. Suggested themes for women faculty-resident discussions.

Negotiations: how to negotiate for a job; how to negotiate in the clinical setting with the health care team and consultants

Work-life balance: childcare options, particularly with irregular clinical schedules; dual-career families; challenges for evening-heavy clinical schedules; scheduling options such as working nights only

Interviewing: how to interview others; how to prepare to be interviewed; interview follow-up norms

Mentorship: how to find a mentor; how to maximize benefit from a mentoring relationship; mentorship outside emergency medicine

Leadership: clinical leadership in the emergency department; attaining leadership positions departmentally, institutionally and nationally; preparing for leadership positions

Public speaking: how to overcome fear; how to prepare a presentation; how to engage an audience; how to deliver a talk; how to access speaking engagements

Managing up: incorporating your leaders' expectations into your work plan

Communication: communication skills in the clinical setting; advocating with the boss or other leadership; techniques for collaboration; how to work with your assistant

Research careers: how to find a research mentor; strategies for educational research

Shift work: how to recover from constantly-changing work hours; how to maintain productivity with an unpredictable schedule; strategies to optimize shift scheduling

Lean In: Women, Work and the Will to Lead (book by Sheryl Sandberg) ${ }^{9}$ : discusses why women lag behind men in leadership roles, and solutions for women to achieve their potential

“Manage energy, not time," (article by Tony Schwartz and Catherine McCarthy) ${ }^{10}$ : discusses how to pace oneself and strategies to recover from intense periods of work

academics, underscore the need for programs tailored to women in residency training. ${ }^{8}$

Integrating such programs into a postgraduate curriculum requires an understanding of the competing demands of the intended audience and knowledge about existing educational gaps and learning needs, in order to create resilient mentoring themes. To maximize participation and learning, the program cannot create untenable demands on the resident and should be incorporated in a way that does not detract from clinical learning and does not alienate male residents. ${ }^{11}$

Our program has been well-received, as shown by strong event attendance and participation. Over twothirds of our women residents have attended each evening event. Clinical work has been the most commonly cited reason for not attending. Residents have commented about the supportive community that has been fostered.

Evidence suggests that assigned mentoring programs are not as productive as those derived from personal preferences and career objectives. ${ }^{12}$ Our program has fostered productive mentoring for many residents that has extended beyond the events themselves. Since the link between mentorship and career choice has been demonstrated, enhanced mentorship by academic women faculty may encourage more women trainees to pursue academic careers. ${ }^{5-7}$ The online resources are easily accessible and provide education in core academic and leadership skills. We plan to encourage their ongoing active use by providing asynchronous learning credits (credit for approved, alternate learning outside the traditional curriculum). Given EM residents' highly variable schedules, this is an important element in increasing outreach.

Given the program's initial success, we continue to expand and seek ways to improve. We are incorporating resident-only events to encourage peer-to-peer mentorship. This provides a unique perspective to junior residents and highlights the importance of mentorship. We are creating teaching case studies about women in academic medicine for residency didactics. The audience would include male residents who may be future EM leaders and thus will benefit from such education. Our program is a low-cost, low-resource and potentially highly significant intervention that other residency programs may easily adopt.

\section{SUMMARY}

Given the disparate representation of male and female physicians on academic faculties and in leadership positions, providing access to relatable role models and mentorship is important. Residency training is a critical juncture at which to intervene. Our implementation of a multifaceted program to increase mentorship and education has been well-received. This program 
promotes the acknowledgement, exploration, discussion, and learning about issues that women encounter in the academic setting. Our model may be useful to other EM residency programs with this mission.

Acknowledgments: We would like to acknowledge the residents' leaders, past and present, who made this educational program possible: Drs. Munirih Qualls, Radhika Sundararajan, Laura Janneck, Daphne Morrison Ponce, R. Eleanor Anderson, Emily Brumfield, Kathleen Davenport. We also thank Dr. Hanni Stoklosa for her leadership as a resident and her assistance now as a faculty member. All authors hold leadership positions in the Harvard Affiliated Emergency Medicine Residency.

Competing Interests: None to declare.

\section{REFERENCES}

1. Cydulka RK, D'Onofrio G, Schneider S, et al. Women in academic emergency medicine. Acad Emerg Med 2000;7(9): 999-1007.

2. Reed DA, Ender F, Lindor R, et al. Gender differences in academic productivity and leadership appointments of physicians throughout academic careers. Acad Med 2011;86(1): 43-7.

3. Levine RB, Lin F, Kern DE, et al. Stories from early-career women physicians who have left academic medicine: a qual itative study at a single institution. Acad Med 2011;86(6):752-8.
4. Welch JL, Jimenez HL, Walthall J, et al. Women in emergency medicine mentoring program: an innovative approach to gender mentoring in graduate medical education. 7 Grad Med Educ 2012;4(3):362-6.

5. Sambunjak D, Straus SE, Marusic A. Mentoring in academic medicine: a systematic review. FAMA 2006;296(9):1103-15.

6. Borges N, Navarro AM, Grover AC. Women physicians: choosing a career in academic medicine. Acad Med 2012; 87(1):105-14.

7. Cain JM, Schulkin J, Parisi ML, et al. Effects of perceptions and mentorship on pursuing a career in academic medicine in obstetrics and gynecology. Acad Med 2001;76(6): 628-34.

8. Straus SE, Straus C, Tzanetos K. Career choice in academic medicine: systematic review. 7 Gen Intern Med 2006;21(12): 1222-9.

9. Sandberg S. Lean in: Women, Work and the Will to Lead. New York: Alfred A. Knopf; 2013.

10. Schwartz T., McCarthy C. Manage Your Energy, Not Your Time. Harvard Business Review. October 2007. https://hbr.org/2007/10/manage-your-energy-not-your-time.

11. Kern DE, Thomas PA, Hughes MT, eds. Curriculum Development for Medical Education - A Six-Step Approach. 2nd ed. Baltimore: The Johns Hopkins University Press; 2009.

12. Yamada K, Slanetz PJ, Boiselle PM. Perceived benefits of a radiology resident mentoring program: comparison of residents with self-selected vs. assigned mentors. Can Assoc Radiol 7 2014;65(2):186-91. 